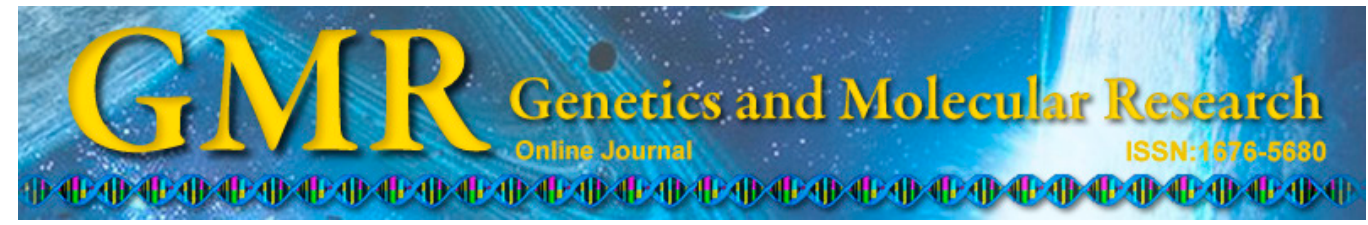

\title{
High-resolution melting curve analysis of the $A D S L$ and $L P L$ genes and their correlation with meat quality and blood parameters in chickens
}

\author{
X.D. Zhang', Q.H. Li ${ }^{1}$, L.F. Lou ${ }^{1}$, J. Liu ${ }^{2}$, X.H. Chen ${ }^{3}$, C.X. Zhang ${ }^{3}$ and \\ H.H. Wang ${ }^{1}$ \\ ${ }^{1}$ Hangzhou Academy of Agricultural Sciences, Hangzhou, China \\ ${ }^{2}$ China Jiliang University, Hangzhou, China \\ ${ }^{3}$ Zhejiang Guangda Poultry Breeding Company, Hangzhou, China \\ Corresponding author: X.D. Zhang \\ E-mail: bigzhengliang@hotmail.com
}

Genet. Mol. Res. 14 (1): 2031-2040 (2015)

Received February 20, 2014

Accepted May 22, 2014

Published March 20, 2015

DOI http://dx.doi.org/10.4238/2015.March.20.13

ABSTRACT. Adenylosuccinate lyase (ADSL) and lipoprotein lipase
(LPL) are key enzymes in the metabolism of inosine monophosphate
(IMP) and fat mass, which are important factors in meat quality
evaluation. In this study, we selected 50 hens from the ISA B-line layers
and Guangxi Yellow chickens, slaughtered the chickens at 120 days old,
and analyzed polymorphisms in the $A D S L$ and $L P L$ genes using the high-
resolution melting curve method. Blood lipid parameters, intramuscular
fat (IMF), and IMP content were higher (P $<0.05$ ) in Guangxi Yellow
chickens than in ISA B-line layers, while LPL activity was lower (P <
0.05). In exon 2 of the $A D S L$ gene, a C3484T mutation was identified.
In both breeds, the CC genotype showed the highest IMP, and IMP was
the lowest in the TT genotype. In the 5 ' regulatory region of the $L P L$
gene, a C293T mutation was identified. In both breeds, the CC genotype
showed the lowest LPL and IMF, while IMF was the highest in the TT
genotype. The percentages of individuals with the TT type in the $A D S L$ 
gene, which was associated with the lowest IMP, were 16.0 and $52.0 \%$ in Guangxi chickens and ISA layers, respectively. The percentages of individuals with the CC type of the $L P L$ gene, which was associated with the lowest LPL and IMF, were 28.0 and $44.0 \%$, respectively. The $A D S L$ and $L P L$ gene mutations are correlated with differences in meat quality in different chicken breeds, and high-resolution melting curve is an effective prediction technology for these mutations.

Key words: Adenylosuccinate lyase gene; Chinese chicken breed; High-resolution melting curve technology; Lipoprotein lipase gene; Meat quality

\section{INTRODUCTION}

The production of high-quality chicken in China is focused on meat quality. Although a standard method for evaluating meat has not been determined, differences in the meat quality of different chicken breeds are well-known. Previous studies showed that inosine monophosphate (IMP) content is an important factor in meat flavor (Manabe et al., 1991; Maga and Shahidi, 1994; Kawai et al., 2002), while intramusclar fat (IMF) content is closely related to meat tenderness, shear force, flavor, and succulence (Bejerholm and Bartongade, 1986; Eikelenboom et al., 1996; Fernandez et al., 1999). Previous studies also indicated that adenylosuccinate lyase (ADSL) catalyzes a 2-step reaction in the purine nucleotide biosynthesis pathway. ADSL has an important influence on final IMP content and plays a vital role in maintaining normal cell division and metabolism (Xu et al., 2011). Lipoprotein lipase (LPL) is a water-soluble enzyme that is synthesized and secreted by fat cells, skeletal muscle cells, and myocardial cells, but mainly by catalytic chylous particles and very low-density lipoproteins. LPL produces fatty acids and glycerol from triglycerides for cellular use and is a key enzyme in fat metabolism (Beisiegel and Heeren, 1997; Mead et al., 2002).

Single-nucleotide polymorphisms (SNPs) can be used as molecular genetic markers. Denaturing gradient gel electrophoresis, capillary electrophoresis, and TaqMan probes are currently used for SNP identification and screening. However, these methods are often subjected to low sensitivity and high false-positive rates. Direct DNA sequencing is more accurate but also more expensive. High-resolution melting curve (HRM) technology is based on efficient robust quantitative fluorescence polymerase chain reaction (PCR), without the need for a sequencespecific probe. The amplification products can be melted through precise warming, allowing for the detection of single-base differences. Thus, HRM has the advantages of being a simple, fast, and low-cost technique that provides accurate results and good repeatability (Tricarico et al., 2011). In this study, we selected 2 different chicken breeds and analyzed polymorphisms in the $A D S L$ and $L P L$ genes using HRM. Combined with the analysis of meat quality and blood lipid indicators, we discuss the molecular basis of meat quality differences.

\section{MATERIAL AND METHODS}

\section{Animals and feeding management}

Two chicken breeds, ISA B-line layers and Guangxi Yellow chickens (a domestic chick- 
en breed in China), were obtained from the Guangda poultry breeding company in Zhejiang Province. ISA B-line layers (IB) had been bred for 14 generations. Guangxi Yellow chickens (GY) were collected from Rongxian County in Guangxi Province and had been bred for 10 generations. Various reproductive and body weight traits of the 2 populations are shown in Table 1.

\begin{tabular}{|c|c|c|c|c|c|c|c|}
\hline \multirow[t]{2}{*}{ Breeds } & \multicolumn{2}{|c|}{ Body weight of cock (g) } & \multicolumn{2}{|c|}{ Body weight of hen (g) } & \multirow[t]{2}{*}{ Age at first egg (day) } & \multicolumn{2}{|c|}{ Egg production } \\
\hline & 60th day & Adult & 60th day & Adult & & 300th day & 500th day \\
\hline $\mathrm{IB}$ & 814 & 2450 & 642 & 1920 & 129th & 136 & 283 \\
\hline GY & 722 & 1895 & 617 & 1495 & 144th & 88 & 146 \\
\hline
\end{tabular}

All test birds were hatched on the same day and then grown indoors and grouped by breed. They were fed a maize-soybean diet that contained 11.9 megajoule $/ \mathrm{kg}$ of metabolizable energy (ME) and $192 \mathrm{~g} / \mathrm{kg}$ of Crude Protein (CP) from 1-56 days, 11.2 megajoule $/ \mathrm{kg}$ of ME, and $158 \mathrm{~g} / \mathrm{kg}$ of CP from 57-120 days.

\section{Slaughter and sample collection}

Fifty hens of each breed were randomly collected at 120 days old. From each chicken, $1.5 \mathrm{~mL}$ blood was collected via the wing vein and placed in a centrifuge tube containing 8 $\mathrm{mL} 70 \%$ ethanol, and then stored at $-20^{\circ} \mathrm{C}$ for DNA analysis. Serum was collected from each chicken after coagulation of at least $1.5 \mathrm{~mL}$ blood at room temperature for $4 \mathrm{~h}$. The sample was stored at $-20^{\circ} \mathrm{C}$ until biochemical analysis.

The study chickens were fasted for $12 \mathrm{~h}$ and their live body weights were recorded. The chickens were then slaughtered and the eviscerated weight, the weights of abdominal fat, breast meat, and leg meat were measured. All weights were determined in grams. The eviscerated weight was the slaughtered body weight excluding the trachea, esophagus, crop, intestine, spleen, pancreas, gall bladder, reproductive organs, heart, liver, proventriculus, gizzard, abdominal fat, head, and feet. Breast meat weight consisted of the weights of the pectoralis major and minor muscles without the skin. Leg meat weight consisted of the weights of the thigh and drumstick without the bone and skin. Left breast muscles were stored at $-20^{\circ} \mathrm{C}$ for IMF and IMP content determination.

\section{Calculation of meat yields from weight data}

Eviscerated yield was calculated as the ratio of eviscerated weight to live body weight after fasting. The weight percentages of the breast and leg meat were calculated as percentages of the eviscerated weight. The weight percentage of abdominal fat was calculated as a percentage of the sum of the eviscerated weight and abdominal fat weight.

\section{Genomic DNA extraction from blood}

DNA was extracted from each blood sample using a blood genomic DNA extraction kit from Axygen (Hangzhou, China). 


\section{Primer design}

Primers for the ADSL gene(GenBank accession No.AY665559)and $L P L$ gene(GenBank accession No. X60547) were as follows: ADSL-F, 5'GAAGAAGCTGCGCCATGATGTG3'; ADSL-R, 5'CCAGCTCTGCAGGCAGGAAAATGA3'; LPL-F, 5'GTGAAGGATGGGAGGG ACAGC3'; LPL-R, 5'CCCTACAAATCAACCTGGCTCCATC3'.

\section{PCR amplification and HRM analysis}

The 15- $\mu \mathrm{L}$ PCR sample contained the following: $5.5 \mu \mathrm{L}$ DNase-free water, $7.5 \mu \mathrm{L}$ SsoFast EvaGreen supermix (Bio-Rad, Hercules, CA, USA), $0.5 \mu \mathrm{L}$ forward primer, $0.5 \mu \mathrm{L}$ reverse primer, and $1 \mu \mathrm{L}$ template DNA. Using the CFX 96 Quantitative PCR instrument (Bio-Rad), the amplification program was run at $98^{\circ} \mathrm{C}$ for $3 \mathrm{~min}$, wi 40 cycles of denaturation at $98^{\circ} \mathrm{C}$ for $5 \mathrm{~s}$ each, and annealing/extension at $62^{\circ} \mathrm{C}$ for $5 \mathrm{~s}$. For the product fusion program, the initial melting temperature was $75^{\circ} \mathrm{C}$, followed by warming to $95^{\circ} \mathrm{C}$ and an increase of $0.2^{\circ} \mathrm{C}$ every 10 s. HRM analysis was conducted using the Precision Melt Analysis ${ }^{\mathrm{TM}}$ software (Bio-Rad).

\section{DNA sequencing}

PCR products of different genotypes were selected and the DNA was sequenced bidirectionally by the Shanghai Yingjun Biotechnology Company using an ABI 3730xl DNA Analyzer (Foster City, CA, USA).

\section{Determination of serum biochemical index}

Using an ARCHITECT C8000 automatic biochemical analyzer (Abbott Laboratories, Abbott Park, IL, USA), total cholesterol and triglyceride contents in the serum were determined. Using a DENLEY DRAGON Wellscan MK3 Elisa instrument (Thermo Scientific, Waltham, MA, USA), serum samples were analyzed for the presence of LPL enzymes.

\section{IMF and IMP content determination}

As the method introduced in NY/T 821 (MOA, 2004), fat was extracted from $10 \mathrm{~g}$ breast meat using a 2:3 methanol:chloroform solution (60 and $90 \mathrm{~mL}$, respectively). A portion of the extract solution $(50 \mathrm{~mL})$ was poured into a beaker, dried at $105^{\circ} \mathrm{C}$, and weighed to determine IMF content.

Two grams breast meat was added to $3.5 \%$ perchlorate solution, homogenized, and centrifuged. The supernatant was adjusted to $\mathrm{pH} 6.0$ with $5 \mathrm{M}$ sodium hydroxide and kept at a $100-\mathrm{mL}$ constant volume. The solution was filtered through a $0.45-\mu \mathrm{m}$ membrane. To determine IMP content, high-performance liquid chromatography was used.

\section{Statistical analysis}

SNP loci in DNA sequences were determined using the DNASTAR 7.1 software packages (DNASTAR, Inc., Madison, WI, USA). Statistical analysis was conducted using the SPSS 17.0 software (SPSS, Inc., Chicago, IL, USA). Data for traits were normally distributed. Significant 
differences between traits were tested using analysis of variance and Duncan's range tests.

\section{RESULTS}

\section{Meat quality and blood biochemical parameters}

Meat yields, quality, and blood test results are shown in Table 2. The eviscerated yield of Gangxi Yellow chickens was higher than that of ISA B-line layers $(\mathrm{P}<0.05)$, while the leg meat yield was lower than that of ISA $(\mathrm{P}<0.05)$. Abdominal fat yield, blood lipid parameters, and IMF content of Gangxi Yellow chickens were all much lower than those of the ISA B-line layers $(\mathrm{P}<0.01)$, while LPL activity and IMP content were much higher than for ISA $(\mathrm{P}<0.01)$.

Table 2. Slaughtered-meat quality and blood biochemical traits (means \pm SD).

\begin{tabular}{llllllllll}
\hline Breeds & \multicolumn{1}{c}{ EP (\%) } & AFP (\%) & LMP (\%) & BMP (\%) & TC $(\mathrm{mM})$ & TG (mM) & LPL (U/mL) & IMF (\%) & IMP $(\mathrm{g} / \mathrm{kg})$ \\
\hline IB & $65.4 \pm 1.8$ & $1.7 \pm 1.4$ & $24.6 \pm 1.9$ & $16.2 \pm 1.4$ & $3.94 \pm 0.70$ & $1.18 \pm 0.41$ & $684.1 \pm 237.5$ & $1.39 \pm 0.21$ & $2.155 \pm 0.303$ \\
GY & $66.5 \pm 1.7^{*}$ & $0.2 \pm 0.1^{* *}$ & $23.4 \pm 1.9^{*}$ & $15.7 \pm 1.0$ & $2.87 \pm 0.31^{* *}$ & $0.53 \pm 0.04 * *$ & $956.7 \pm 318.9^{* *}$ & $1.06 \pm 0.12^{* *}$ & $2.597 \pm 0.375^{* *}$ \\
\hline
\end{tabular}

$\mathrm{EP}=$ eviscerated yield; $\mathrm{AFP}=$ abdominal fat yield; $\mathrm{LMP}=$ leg meat yield; $\mathrm{BMP}=$ breast meat yield; TC $=$ total cholesterol; $\mathrm{TG}=$ total triglyceride; $\mathrm{LPL}=$ lipoprotein lipase; $\mathrm{IMF}=$ intramuscular fat; $\mathrm{IMP}=$ inosine monophosphate. *Significant difference in means between breeds $(\mathrm{P}<0.05)$; **highly significant difference in means between breeds $(\mathrm{P}<0.01)$.

\section{HRM genotype detection and DNA sequencing results}

The HRM melting curve, difference curve, and classification sequence results for the $A D S L$ gene are shown in Figure 1. In exon 2 of the ADSL gene, a C3484T mutation was identified. The HRM technique be used to can detect the CC wild-type, the CT heterologous mutation, and the TT homologous mutation.

The HRM melting curve, difference curve, and the classification sequence results for the $L P L$ gene are shown in Figure 2. In the 5 ' regulatory region of the $L P L$ gene, a C293T mutation was identified, and HRM techniques can be used to detect the CC wild-type, the CT heterologous mutation, and the TT homologous mutation.

\section{Genotype frequency and gene frequency analysis}

Gene, genotype frequency, and Homals fitness test of the 2 genes are shown in Table 3. The ADSL gene was found to be in Hardy-Weinberg equilibrium $(\mathrm{P}>0.05)$, while the $L P L$ gene deviated significantly from the Hardy-Weinberg model $(\mathrm{P}<0.05)$.

\section{Trait comparison between different genotypes}

Slaughter and blood lipid parameters of the different ADSL genotypes of the 2 chicken breeds are shown in Table 4 . The CC wild-type genotype had the lowest LPL activity and IMF content, while the CT type had the highest; however, the differences were insignificant $(\mathrm{P}>$ $0.05)$. IMP content between the 3 genotypes was significant. The $\mathrm{CC}$ type showed the highest value, while the TT type was the lowest $(\mathrm{P}<0.05)$. 

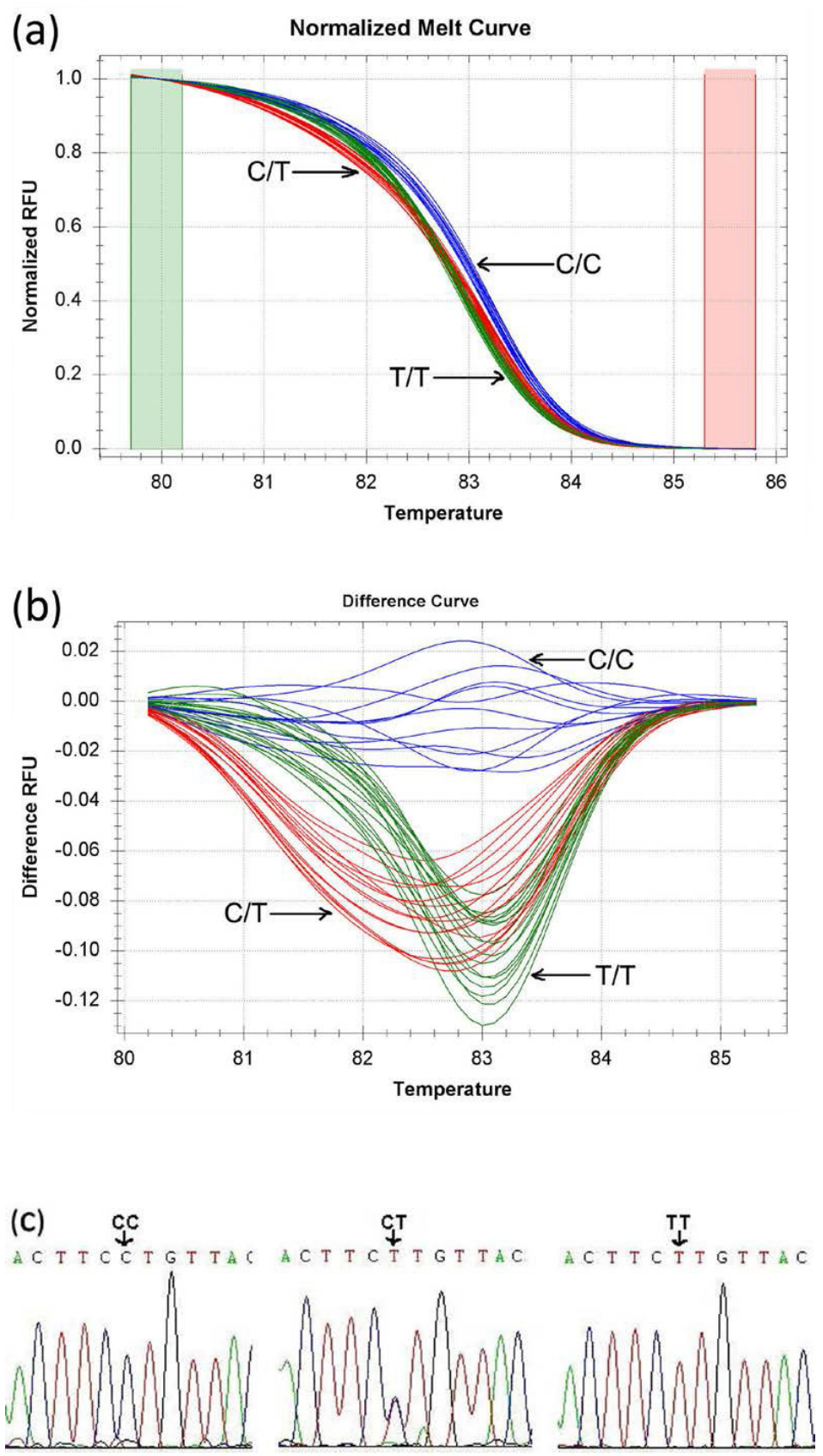

Figure 1. a. HRM melting curve for the $A D S L$ gene. Relative fluorescence units are on the Y-axis and temperature in ${ }^{\circ} \mathrm{C}$ is on the $\mathrm{X}$-axis. Green and red columns represent pre- and post-melting normalization regions. b. HRM difference curve for the $A D S L$ gene. Difference in relative fluorescence units is on the Y-axis and temperature in ${ }^{\circ} \mathrm{C}$ is on the $\mathrm{X}$-axis. CC genotype samples are the reference curves. c. Sequencing peak of the ADSL gene. The CC, $\mathrm{CT}$, and TT genotypes are indicated from left to right. 

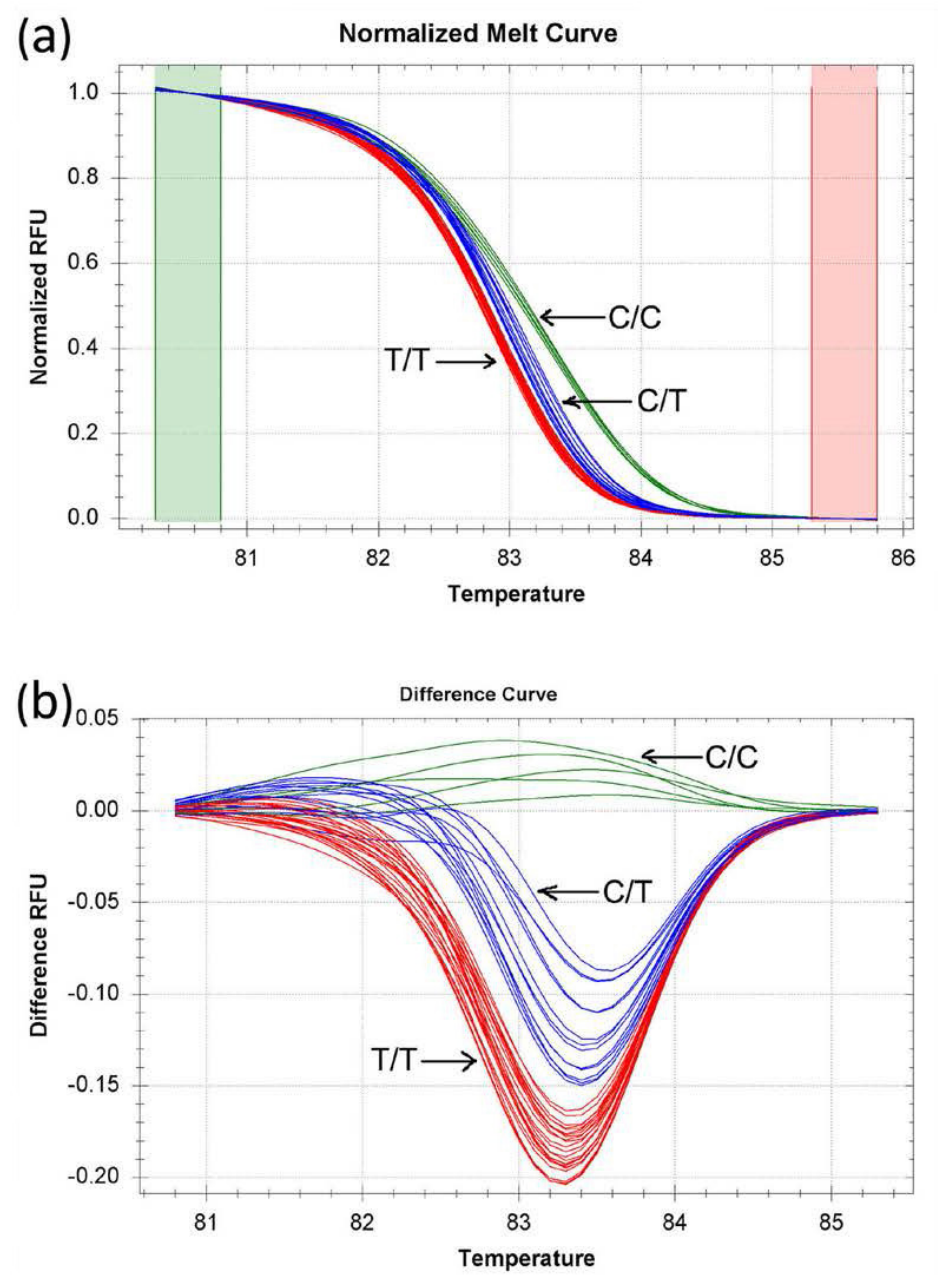

(c)

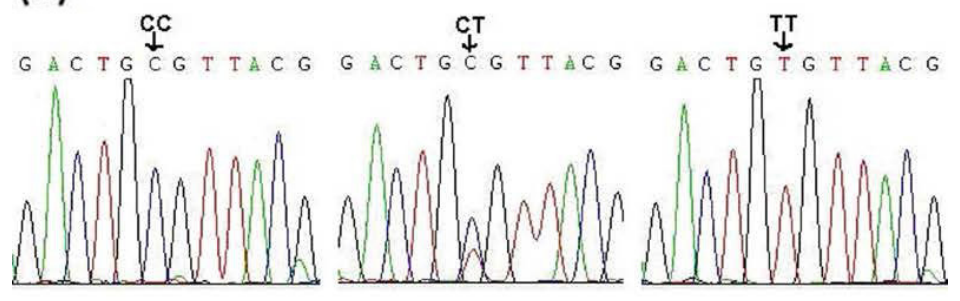

Figure 2. a. HRM melting curve for the $L P L$ gene. Relative fluorescence units are on the Y-axis and temperature in ${ }^{\circ} \mathrm{C}$ is on the $\mathrm{X}$-axis. Green and red columns represent pre- and post-melting normalization regions. b. HRM difference curve for the $L P L$ gene. Difference in relative fluorescence units is on the Y-axis and temperature in ${ }^{\circ} \mathrm{C}$ is on the $\mathrm{X}$-axis. CC genotype samples are the reference curves. c. Sequencing peak of the $L P L$ gene. The CC, CT, and TT genotypes are indicated from left to right. 
Table 3. Genotype and gene frequencies.

\begin{tabular}{|c|c|c|c|c|c|c|c|c|}
\hline \multirow[t]{2}{*}{ Gene } & \multirow[t]{2}{*}{ Breeds } & \multirow[t]{2}{*}{ Numbers } & \multicolumn{3}{|c|}{ Genotype frequency } & \multicolumn{2}{|c|}{ Gene frequency } & \multirow[t]{2}{*}{ Chi-square values } \\
\hline & & & $\mathrm{CC}$ & $\mathrm{CT}$ & TT & $\mathrm{C}$ & $\mathrm{T}$ & \\
\hline \multirow[t]{2}{*}{$A D S L$} & IB & 50 & 0.50 & 0.34 & 0.16 & 0.67 & 0.33 & 2.67 \\
\hline & GY & 50 & 0.14 & 0.34 & 0.52 & 0.31 & 0.69 & 2.11 \\
\hline \multirow[t]{2}{*}{$L P L$} & IB & 50 & 0.28 & 0.32 & 0.40 & 0.44 & 0.56 & $6.15^{*}$ \\
\hline & GY & 50 & 0.44 & 0.26 & 0.30 & 0.57 & 0.43 & $11.03 * *$ \\
\hline
\end{tabular}

*Significant difference between means $(\mathrm{P}<0.05)$; **highly significant difference between means $(\mathrm{P}<0.01)$. $\chi_{0.05(\mathrm{df}=1)}^{2}=3.841 ; \chi_{0.01(\mathrm{df}=1)}^{2}=6.635$.

Table 4. Effect of ADSL genotype on traits in ISA B-line layers and Guangxi yellow chickens.

\begin{tabular}{lcccccccccc}
\hline Breeds & Genotypes & EP $(\%)$ & AFP $(\%)$ & LMP $(\%)$ & BMP $(\%)$ & TC $(\mathrm{mM})$ & TG $(\mathrm{mM})$ & LPL $(\mathrm{U} / \mathrm{mL})$ & IMF $(\%)$ & IMP $(\mathrm{g} / \mathrm{kg})$ \\
\hline IB & CC & $66.1^{\mathrm{a}}$ & $0.15^{\mathrm{a}}$ & $15.9^{\mathrm{a}}$ & $22.5^{\mathrm{a}}$ & $3.07^{\mathrm{a}}$ & $0.60^{\mathrm{b}}$ & $797.5^{\mathrm{a}}$ & $1.02^{\mathrm{a}}$ & $2.708^{\mathrm{c}}$ \\
& CT & $66.5^{\mathrm{a}}$ & $0.25^{\mathrm{a}}$ & $15.8^{\mathrm{a}}$ & $23.5^{\mathrm{a}}$ & $2.79^{\mathrm{a}}$ & $0.53^{\mathrm{a}}$ & $1055.2^{\mathrm{a}}$ & $1.10^{\mathrm{a}}$ & $2.369^{\mathrm{b}}$ \\
\multirow{4}{*}{ GY } & TT & $66.6^{\mathrm{a}}$ & $0.21^{\mathrm{a}}$ & $15.6^{\mathrm{a}}$ & $23.7^{\mathrm{a}}$ & $2.86^{\mathrm{a}}$ & $0.51^{\mathrm{a}}$ & $945.1^{\mathrm{a}}$ & $1.05^{\mathrm{a}}$ & $1.935^{\mathrm{a}}$ \\
& CC & $65.9^{\mathrm{a}}$ & $1.35^{\mathrm{a}}$ & $16.0^{\mathrm{a}}$ & $24.8^{\mathrm{a}}$ & $3.85^{\mathrm{a}}$ & $1.16^{\mathrm{a}}$ & $641.2^{\mathrm{a}}$ & $1.34^{\mathrm{a}}$ & $2.778^{\mathrm{a}}$ \\
& CT & $64.9^{\mathrm{a}}$ & $1.49^{\mathrm{ab}}$ & $15.9^{\mathrm{a}}$ & $24.5^{\mathrm{a}}$ & $4.04^{\mathrm{a}}$ & $1.21^{\mathrm{a}}$ & $762.8^{\mathrm{a}}$ & $1.48^{\mathrm{a}}$ & $2.380^{\mathrm{b}}$ \\
& TT & $65.0^{\mathrm{a}}$ & $3.00^{\mathrm{b}}$ & $17.4^{\mathrm{a}}$ & $24.4^{\mathrm{a}}$ & $4.11^{\mathrm{a}}$ & $1.25^{\mathrm{a}}$ & $696.5^{\mathrm{a}}$ & $1.36^{\mathrm{a}}$ & $2.083^{\mathrm{a}}$ \\
\hline
\end{tabular}

$\mathrm{EP}=$ eviscerated yield; AFP = abdominal fat yield; LMP = leg meat yield; BMP = breast meat yield; TC $=$ total cholesterol; $\mathrm{TG}=$ total triglyceride; $\mathrm{LPL}=$ lipoprotein lipase; $\mathrm{IMF}=$ intramuscular fat; IMP $=$ inosine monophosphate. Small superscript letters indicate significant differences in means within the breed $(\mathrm{P}<0.05)$.

Slaughter and blood lipid parameters of the different $L P L$ genotypes of both breeds of chickens are shown in Table 5. The CT genotype showed the lowest abdominal fat yield (P $>0.05)$, total cholesterol, and triglyceride content $(\mathrm{P}<0.05)$, while this type had the highest LPL activity $(\mathrm{P}>0.05)$. Expressions of the CC genotype were the opposite, and the CC type had the lowest IMF content and the TT type had the highest $(\mathrm{P}<0.05)$.

Table 5. Effect of LPL genotype on traits in ISA B-line layers and Guangxi yellow chickens.

\begin{tabular}{lcccccccccc}
\hline Breeds & Genotypes & EP $(\%)$ & AFP $(\%)$ & LMP $(\%)$ & BMP $(\%)$ & TC $(\mathrm{mM})$ & TG $(\mathrm{mM})$ & LPL $(\mathrm{U} / \mathrm{mL})$ & IMF $(\%)$ & IMP $(\mathrm{g} / \mathrm{kg})$ \\
\hline IB & CC & $66.0^{\mathrm{a}}$ & $0.22^{\mathrm{a}}$ & $15.6^{\mathrm{a}}$ & $23.1^{\mathrm{a}}$ & $2.95^{\mathrm{b}}$ & $0.55^{\mathrm{b}}$ & $934.9^{\mathrm{a}}$ & $0.95^{\mathrm{a}}$ & $2.263^{\mathrm{a}}$ \\
& CT & $66.5^{\mathrm{a}}$ & $0.15^{\mathrm{a}}$ & $16.2^{\mathrm{a}}$ & $23.9^{\mathrm{a}}$ & $2.56^{\mathrm{a}}$ & $0.49^{\mathrm{a}}$ & $989.2^{\mathrm{a}}$ & $1.08^{\mathrm{b}}$ & $2.233^{\mathrm{a}}$ \\
& TT & $67.1^{\mathrm{a}}$ & $0.23^{\mathrm{a}}$ & $15.6^{\mathrm{a}}$ & $23.6^{\mathrm{a}}$ & $2.90^{\mathrm{b}}$ & $0.52^{\mathrm{ab}}$ & $967.7^{\mathrm{a}}$ & $1.18^{\mathrm{c}}$ & $2.111^{\mathrm{a}}$ \\
GY & CC & $65.5^{\mathrm{a}}$ & $1.93^{\mathrm{a}}$ & $16.9^{\mathrm{a}}$ & $25.2^{\mathrm{a}}$ & $4.16^{\mathrm{a}}$ & $1.28^{\mathrm{b}}$ & $666.0^{\mathrm{a}}$ & $1.16^{\mathrm{a}}$ & $2.505^{\mathrm{a}}$ \\
& CT & $65.3^{\mathrm{a}}$ & $1.52^{\mathrm{a}}$ & $16.0^{\mathrm{a}}$ & $25.1^{\mathrm{a}}$ & $3.80^{\mathrm{a}}$ & $1.01^{\mathrm{a}}$ & $730.0^{\mathrm{a}}$ & $1.34^{\mathrm{b}}$ & $2.648^{\mathrm{a}}$ \\
& TT & $65.5^{\mathrm{a}}$ & $1.56^{\mathrm{a}}$ & $15.9^{\mathrm{a}}$ & $24.1^{\mathrm{a}}$ & $3.88^{\mathrm{a}}$ & $1.23^{\mathrm{b}}$ & $671.6^{\mathrm{a}}$ & $1.54^{\mathrm{a}}$ & $2.538^{\mathrm{a}}$ \\
\hline
\end{tabular}

$\mathrm{EP}=$ eviscerated yield; AFP $=$ abdominal fat yield; $\mathrm{LMP}=$ leg meat yield; BMP $=$ breast meat yield; TC $=$ total cholesterol; TG $=$ total triglyceride; $\mathrm{LPL}=$ lipoprotein lipase; IMF = intramuscular fat; IMP = inosine monophosphate. Small superscript letters indicate significant differences in means within breeds $(\mathrm{P}<0.05)$.

\section{DISCUSSION}

\section{HRM technique and its application for detecting genotypes affecting meat quality}

HRM analysis has been used to detect genetic mutations that cause human diseases in genes such as RET, CFTR, and PEX6 (Margraf et al., 2007; Audrezet et al., 2008; Ebberink et al., 2010). Poultry infectious bronchitis and infectious bursal disease virus mutations have 
been detected and reported previously (Hewson et al., 2010; Ghorashi et al., 2011). Based on our results, the HRM technique is very simple and fast, and the classification of the results is relatively clear, making HRM an ideal method for detecting SNPs in genes related to meat quality. In this study, gene amplification from only 1 mutation was detected. If more than 1 SNP is present, classification may be more complex.

\section{Parameters associated with the $A D S L$ and $L P L$ genes}

Shu et al. (2007) examined the ADSL gene for SNPs in exon 2 in 6 chicken breeds. Ye et al. (2010), for the Beijing You chicken, found 1 polymorphism locus (C3484T); the breast IMP content was significantly different among genotypes. Our results confirmed that C3484T mutations cause differences in IMP and that IMP content is lower in the homologous mutant TT type, which is consistent with the results of Ye.

$\mathrm{Mu}$ et al. (2005), using PCR-single-strand conformation polymorphism and sequence analysis on high- and low-fat of broilers for nucleotide variation in the $L P L$ gene, found that the LPL gene mutations C235T, C278T, and C293T significantly impacted body weight and abdominal fat. In our study, only the C293T mutation was detected, which may have been related to different chicken breeds and sample numbers. The results showed that the CC type had the lowest lipoprotein lypase and intramuscular fat, while total cholesterol and triglyceride content were the highest. The $L P L$ gene and its mutations may play an important role in regulating fat content.

\section{Differences between chicken breeds}

Meat quality and flavor are a result of interactions between components such as muscle, fat, and connective tissues. IMP content differs in different chicken breeds or lines (Huang et al., 1994; Chen et al., 2005; Tang et al., 2009); fat deposition location, content, and capacity also differ (Lv et al., 2011). Based on meat traits, GY is known for its tender and delicious meat, and IB has relatively poor meat quality as egg chicken breed. The percentages of individuals with the TT type of the $A D S L$ gene with the lowest IMP content in GY and IB chickens were respectively 16.0 and $52.0 \%$, while the percentages with the CC type of the $A D S L$ gene with the highest IMP content were 50.0 and $14.0 \%$. The percentages of individuals with the CC type of the $L P L$ gene that produced the lowest IMF content in GY and IB chickens were respectively 28.0 and $44.0 \%$, while the percentages with the TT type of the $L P L$ gene that produced the highest IMF were 40.0 and $30.0 \%$. These results relate genotype and meat quality. The detection of genes affecting meat quality may be an effective method for developing modern breeding programs.

\section{REFERENCES}

Audrezet MP, Dabricot A, Le Marechal C and Ferec C (2008). Validation of high-resolution DNA melting analysis for mutation scanning of the cystic fibrosis transmembrane conductance regulator (CFTR) gene. J. Mol. Diagn. 10: 424-434.

Beisiegel U and Heeren J (1997). Lipoprotein lipase (EC 3.1.1.34) targeting of lipoproteins to receptors. Proc. Nutr. Soc. 56: 731-737.

Bejerholm C and Bartongade PA (1986). Effect of Intramuscular Fat Level on Eating Quality of Pig Meat. Proc. 32nd European Meeting Of Meat Research Workers. Vol. II. Ghent, 389-391. 
Chen JL, Wen J, Wang SB and Zhao GP (2005). Studies on the characteristics of deposition of chicken IMP and IMF. Acta Vet. Zootechnol. Sin. 36: 843-845.

Ebberink MS, Kofster J, Wanders RJ and Waterham HR (2010). Spectrum of PEX6 mutations in Zellweger syndrome spectrum patients. Hum. Mutat. 31: E1058-E1070.

Eikelenboom G, Hoving-bolink AH and Van der wal PG (1996). The eating quality of pork. 2. The influence of intramuscular fat. Fleischwirtchaft 76: 559-560.

Fernandez X, Monin G, Talmant A, Mourot J, et al. (1999). Influence of intramuscular fat content on the quality of pig meat - 1. Composition of the lipid fraction and sensory characteristics of m. longissimus lumborum. Meat Sci. 53: 59-65.

Ghorashi SA, O'Rourke D, Ignjatovic J and Noormohammadi AH (2011). Differentiation of infectious bursal disease virus strains using real-time RT-PCR and high resolution melt curve analysis. J. Virol. Methods 171: 264-271.

Hewson KA, Browning GF, Devlin JM, Ignjatovic J, et al. (2010). Application of high-resolution melt curve analysis for classification of infectious bronchitis viruses in field specimens. Aust. Vet. J. 88: 408-413.

Huang MN, Li JF and Yu L (1994). Inosine Acid and Glutamic Acid Content Comparison Among Different Chicken Breeds. The 3rd Symposium on Improvement, Production and Development of High Quality Chickens. Chung Hsing Univ., Taiwan, 175-178.

Kawai M, Okiyama A and Ueda Y (2002). Taste enhancements between various amino acids and IMP. Chem. Senses 27: 739-745.

Lv XQ, Liu RR, Zhao GP and Zheng MQ (2011). Methodology study on measurement of body fat distribution in high quality chicken. China Poult. 33: 15-18.

Maga JA and Shahidi F (1994). Umami Flavor in Meat. Flavor of Meat and Meat Products. Chapman and Hall, Glasgow, 98-115.

Manabe KM, Matoba T and Hasegawa K (1991). Sensory changes in umami taste of inosine-5'-monophosphate solution after heating. Food Sci. 56: 1429-1432.

Margraf RL, Mao R, Highsmith WE, Holtegaard LM, et al. (2007). RET proto-oncogene genotyping using unlabeled probes, the masking technique, and amplicon high-resolution melting analysis. J. Mol. Diagn. 9: 184-196.

Mead JR, Irvine SA and Ramji DP (2002). Lipoprotein lipase: structure, function, regulation, and role in disease. J. Mol. Med. 80: 753-769.

MOA (2004). Technical Regulation for Determination of Pork Quality (NY/T 821-2004). Beijing, 4-5.

Mu YS, Wang YX, Wang QG and Li H (2005). Correlation Analysis Between Single Nucleotide Polymorphism of the Lipoprotein Lipase and Fatness Traits in Chickens. The 13th National Symposium on Animal Genetics and Breeding. Northeast Agri. Univ., Heilongjiang, 447-450.

Shu JT, Bao WB, Zhang HX, Zhang XY, et al. (2007). Correlation between adenylosuccinate lyase (ADSL) gene polymorphism and inosine monophosphate acid (IMP) content in domestic fowl and genetic relationship between red jungle fowl and domestic fowl. Yi Chuan 29: 343-348.

Tang H, Gong YZ, Wu CX, Jiang J, et al. (2009). Variation of meat quality traits among five genotypes of chicken. Poult. Sci. 88: 2212-2218.

Tricarico R, Crucianelli F, Alvau A, Orlando C, et al. (2011). High resolution melting analysis for a rapid identification of heterozygous and homozygous sequence changes in the MUTYH gene. BMC Cancer 11: 305.

Xu SJ, Yu DB and Du WX (2011). Current research advances in IMP and related enzymes. Biotechnol. Bull. 3: 44-53.

Ye MH, Chen JL, Zhao GP, Zheng MQ, et al. (2010). Correlation between polymorphisms in ADSL and GARS-AIRSGART genes with inosine 5'-monophosphate (IMP) contents in Beijing-you chickens. Br. Poult. Sci. 51: 609-613. 